\title{
Changes in the Morphology of Influenza Particles Induced at Low pH
}

\author{
By \\ R. W. H. RuigroK ${ }^{1}$, A. F. M. Cremers ${ }^{1}$, \\ W. E. P. BEYER ${ }^{2}$, and F. M. DE RONDE-VERLOop 3 \\ 1 Department of Biochemistry, State University of Leiden, Leiden \\ 2 WHO National Influenza Centre, Erasmus University, Rotterdam \\ ${ }^{3}$ Rijksinstituut voor de Volksgezondheid, Laboratory of Virology, Bilthoven, \\ The Netherlands \\ With 5 Figures \\ Accepted May 11, 1984
}

\begin{abstract}
Summary
At low $\mathrm{pH}$ influenza virus causes membrane fusion. This phenomenon is thought to reflect a part of the infection mechanism of the virus. To obtain more information on the effect of low $\mathrm{pH}$ on the virus, the change in morphology of influena virus particles was studied by electron microscopy. Further, the degradation of hamagglutinin (HA) after trypsin digestion as a function of $p H$ was studied by gel electrophoresis. The results showed that a threshold value existed below which both a change in morphology and an increase in trypsin sensitivity were observed. This threshold $\mathrm{pH}$ was found to be strain specific. A number of strains showed a heterogeneity in the particle population with respect to the threshold pH. The various subpopulations appeared to differ genetically. Virus particles with uncleaved precursor HA, HAo, were not effected by the low pH treatment.
\end{abstract}

\section{Introduction}

Recent investigations have shown that a number of enveloped animal viruses have a common way of infection. The virus particles adhere to the host cell surface and then enter the cell using a general cellular feeding mechanism. In one of the next steps the virus is transported to an acidic vesicle. The sudden drop of the $\mathrm{pH}$ of the environment of the virus triggers a process in which the viral membrane fuses with the vesicle membrane enabling the viral RNA to enter the cytoplasm $(9,31,35)$. A like wise 
entry mechanism is used by diphteria toxin where the low $\mathrm{pH}$ shock also triggers entry (6). Weak bases that raise the $\mathrm{pH}$ in the cellular acidic vesicles can block these infection processes $(3,10)$.

There are indications that influenza virus also follows this infection pathway $(13,21,23)$. The surface glycoprotein haemagglutinin (HA) is thought to mediate the low $\mathrm{pH}$ fusion process $(13,22,30,36)$ by a change in conformation occurring at low $\mathrm{pH}$. This conformational change has been demonstrated by biochemical, physical and immunological techniques (4, $27,30,34$ ). Virus particles in which the precursor haemagglutinin (HAo) is intact do not trigger the low $\mathrm{pH}$ fusion and haemolysis of red blood cells until the protein is cleaved in HA1 and HA2 (36). The presence of HA 1 and $\mathrm{HA}_{2}$ is also a requirement for infection $(16,19,29)$. The Nterminus of HA2, which is generated upon cleavage, shows similarities with the $\mathrm{N}$-terminus of the fusion protein of Sendai virus $(7,29)$. An important difference between the hydrophobic $\mathrm{N}$-termini of the viruses however, is the presence of a number of acidic residues in the HA2 Nterminus. Sendai virus fuses at neutral $\mathrm{pH}$ and the difference with influenza virus in this respect may be due to these acidic residues.

In this paper we describe studies on the $\mathrm{pH}$ dependent behaviour of the HA-molecules of a number of influenza virus strains by electron microscopy and a trypsin sensitivity test. The role of the acidic residues in the HA2 $\mathrm{N}$-terminus is duscussed and the effects of a low $\mathrm{pH}$ treatment on virus with $\mathrm{HAo}$ are also reported. In the experiments some heterogeneity of particles within one strain is found. This heterogeneity is analysed and appears to be associated with a genetic heterogeneity.

\section{Materials and Methods}

\section{Viruses}

Part of the influenza A and B virus strains (Table 1) were propagated in the allantoic cavity of embryonated eggs for two days before harvest. The virus was isolated by pelleting from the allantoic fluid at $25,000 \mathrm{rpm}$ in a $30 \mathrm{Ti}$ rotor for 1 hour. The pellets were first washed with and then taken up in PBS $(140 \mathrm{~mm} \mathrm{NaCl}, 3 \mathrm{~mm}$ KCl, $10 \mathrm{~mm}$ phosphate buffer $\mathrm{pH} 7.0$ ) with 0.001 per cent azide. The strains that were provided by DUPHAR BV were egg-grown and inactivated by 0.01 per cent $\beta$-propiolactone after purification. B/Sing was also tested in active form which was found to behave identical to inactivated virus.

For production of virus with HAo, A/Texas (E16MK4LLC1; MK = monkey kidney; $\mathrm{LLC}=\mathrm{LLC}-\mathrm{MK}_{2} \mathrm{D}$ cells [Flow]) was grown in tertiary eynomolgus monkey kidney (tMK) cells. After virus inoculation tMK cells were maintained in Eagles minimal essential medium supplied with 3 per cent newborn calf serum if intact and supplied with $0.5 \mu \mathrm{g}$ trypsin per $\mathrm{ml}$ if split HA was required. The infected cell cultures were incubated at $33^{\circ} \mathrm{C}$ in roller drums and harvested when all cells showed cytopathic effect. The virus was isolated as described above and purified by centrifugation over a $20-50$ per cent sucrose gradient. Cleavage of HAo after isolation and puri- 
Table 1. Virus strains used in this study

\begin{tabular}{|c|c|c|}
\hline Virus strain & Passage formula ${ }^{a}$ & Abbreviation used \\
\hline $\begin{array}{c}\text { X31 (H3N 2) recombinant: } \\
\text { A/Aichi/2/68-A/PR/8/34 }\end{array}$ & $\mathrm{ExE} 2$ & $\mathrm{X} 31$ \\
\hline $\begin{array}{l}\text { X49 (H3N 2) recombinant: } \\
\text { A/England } / 864 / 75-\mathrm{A} / \mathrm{PR} / 8 / 34\end{array}$ & $\mathrm{D}$ & $\mathrm{X} 49$ \\
\hline $\mathrm{A} / \mathrm{Brazil} / 11 / 78(\mathrm{H} 1 \mathrm{~N} 1)$ & $\mathrm{D}$ & A/Brazil \\
\hline A/Texas/1/77 (H3N2) & $\mathrm{E} 16 \mathrm{E} 2$ & A/Texas \\
\hline $\mathrm{A} / \mathrm{Japan} / 305 / 57(\mathrm{H} 2 \mathrm{~N} 2)$ & $\mathrm{E} 5 \mathrm{~F} 3 \mathrm{M} 6 \mathrm{E} 8$ & A/Japan \\
\hline A/WSN/33 (H 1N 1$)$ & $\mathrm{M} 219 \mathrm{E} 2$ & A/WSN \\
\hline $\mathrm{A} / \mathrm{PR} / 8 / 34(\mathrm{H} 1 \mathrm{~N} 1)$ & FMEM 3 E 64 M 8 E 6 & $\mathrm{~A} / \mathrm{PR} / 8$ \\
\hline A/Victoria/3/75 (H3N2) & E 4 E 10 & A/Vic \\
\hline A/fowl plaque virus/Rostock/34 ( $\mathrm{H} 7 \mathrm{~N} 1)$ & ExE 11 & $\mathrm{~A} / \mathrm{EPV}$ \\
\hline B/Lee $/ 40$ & ExE 7 & B/Lee \\
\hline B/Hong Kong/8/73 & $\mathrm{D}$ & B/Hong Kong \\
\hline $\mathrm{B} /$ Singapore $/ 222 / 79$ & $\mathrm{D}$ & B/Sing \\
\hline
\end{tabular}

a $M$ indicates isolation or passage in mouse; $F$ ferret; $\mathrm{E}$ egg, amniotic or allontoic cavity; D egg-grown virus, kindly provided by DUPHAR (Weesp, The Netherlands)

fication of the HAo virus was done by incubating the virus in $40 \mu \mathrm{g} / \mathrm{ml}$ trypsin (Boehringer) in PBS at $37^{\circ} \mathrm{C}$ for 30 minutes. After this incubation the virus was purified again over a sucrose gradient.

\section{Inoculation of Eggs with Virus Which Was Treated at Low $p H$}

A/WSN virus grown in eggs was purified by adsorption to and elution from chicken red blood cells in PBS. The $\mathrm{pH}$ of the suspension was brought to 5.6 by adding a solution of $\mathrm{KH}_{2} \mathrm{PO}_{4}$ incubated at this $\mathrm{pH}$ for 2 hours at room temperature and used for infection. Subsequently, the harvested virus was purified as described above.

\section{Low $p H$ Treatment}

The low $\mathrm{pH}$ treatments were done by dialyzing the virus against a buffer with the desired $\mathrm{pH}$ in PBS for 24 hours. Then the virus was dialyzed back to $\mathrm{pH} 7$ before further analysis.

\section{Electron Microscopy}

EM preparations were made by adsorbing the virus to carbon film and staining with 1 per cent phospotungstic acid $\mathrm{pH}$ 7. After air-drying the specimens were studied in a Philips EM-300. The magnification of the instrument was calibrated using a grating of 2160 lines/mm (Ladd). The spike layer widths were measured from EM negatives by means of a digitizer (Summagraphics) coupled to a PDP 11/34 computer. For each $\mathrm{pH}$ value the spike layer widths of about 300 particles were measured.

\section{Tests}

The trypsin treatment and subsequent gel electrophoresis were done as deseribed by SKEHEL and coworkers (30). Briefly, virus $(4 \mathrm{mg} / \mathrm{ml})$ was incubated with 1 per cent trypsin $(\mathrm{w} / \mathrm{v})$ in $\mathrm{PBS}$ at $20^{\circ} \mathrm{C}$. After 20 minutes the reaction was stopped with 1 per cent soybean trypsin inhibitor (Worthington). The tryptic products were then analysed by polyacrylamide gel electrophoresis using 12 or 14 per cent gels. The 
haemolysis tests were performed with human red blood cells in PBS according to HosakA et al. (12). The neuraminidase activity was measured according to a WHO standard procedure using fetuin as a substrate (1).

\section{Results}

The conformational change of virus bound HA in intact virus at low $\mathrm{pH}$ was investigated by electron microscopy and a trypsin sensitivity test. All $\mathrm{pH}$ experiments were done by dialyzing the virus to low $\mathrm{pH}$ and then back to $\mathrm{pH} 7$. Thus all the $\mathrm{pH}$ effects reported here are irreversible effects. The behaviour of strain X 49 is described as an example. All strains showed essentially the same changes as a result of the low $\mathrm{pH}$ treatment.
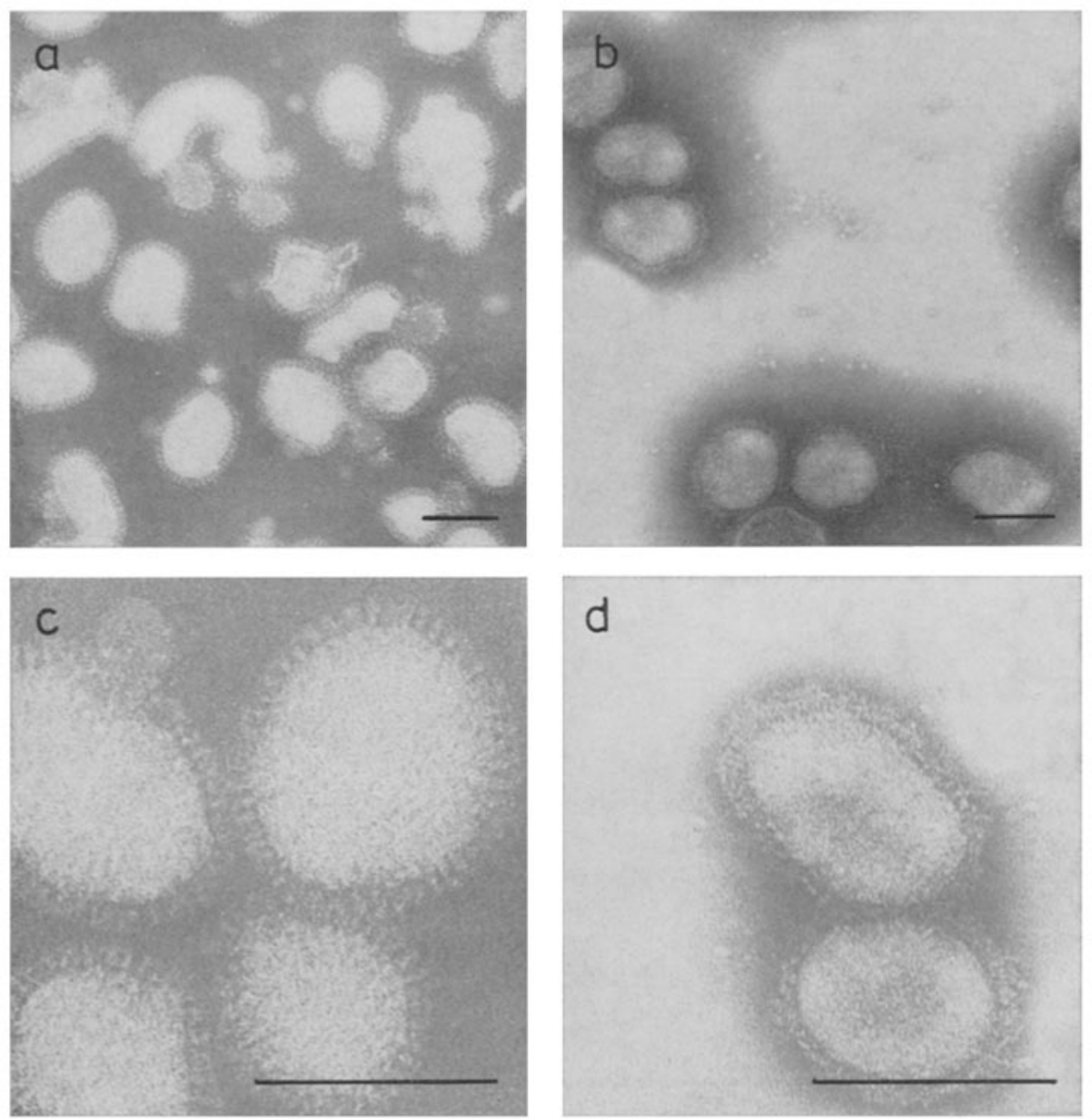

Fig. 1. Typical electron mieroscopie images of influenza $\mathrm{X} 49$ virus. $a$ Native virus.

$b$ Low $\mathrm{pH}$ treated virus. $c$ and $d$ Higher magnifications of a and $\mathrm{b}$, respectively. The bar represents $100 \mathrm{~nm}$ 
Typical images of X 49 virus preparations are given in Fig. 1 . When the virus was dialyzed to $\mathrm{pH}$ values below $\mathrm{pH} 5.1$, the ordered spike structure disappeared. The width of the spike layer was measured. At $\mathrm{pH} 7$ the measured widths of about 300 particles showed a sharp distribution in a histogram, Fig. 2. The mean value was $12 \mathrm{~nm}$. At low pH the histograms

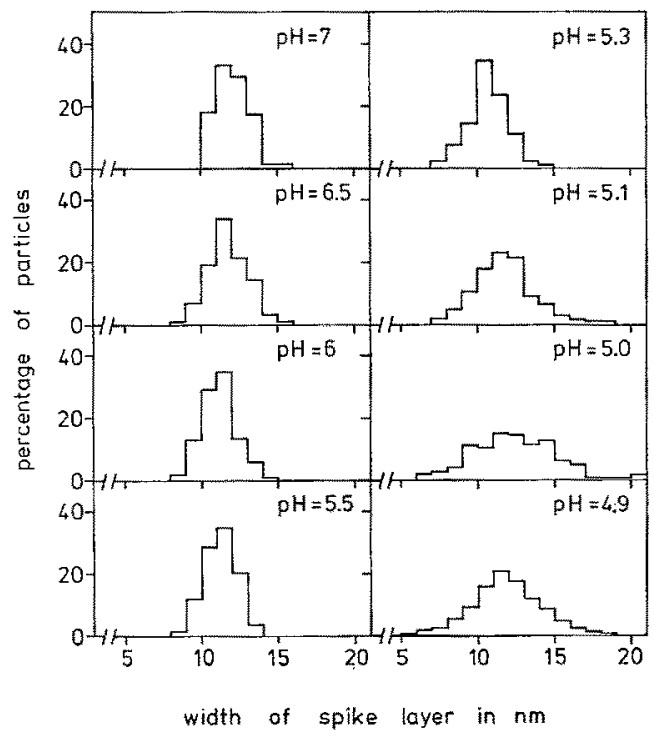

Fig. 2. Histograms of the distribution of spike-layer widths of $\mathrm{X} 49$ virus at different $\mathrm{pH}$ values

broadened, presumably as a result of the conformational change of HA. Sendai virus, which is not dependent on a low $\mathrm{pH}$ for fusion and haemolysis, did not show any change in EM image after dialysis to $\mathrm{pH} 4.5$ (not shown). The disorder of the spike layer of influenza virus is most probably the result of changes in protein because fixation of the viral proteins with 0.25 per cent glutardialdehyde prevented the disappearance of the ordered structure by low $\mathrm{pH}$ treatment.

The trypsin sensitivity of the virus after low $\mathrm{pH}$ treatment was also studied. It was found that HA 1 becomes susceptible to tryptic degradation at the same $\mathrm{pH}$ value (5.1) at which the change in the EM image was observed. Fig. 3 shows a gel pattern of a tryptic digest of $\mathrm{X} 49$ after $\mathrm{pH} 5$

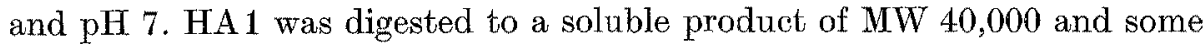
minor products of $\mathrm{MW} 23,000$ and 20,000 .

A number of strains have been analysed in this way and Table 2 gives the $p H$ values at which the conformational change occurred. The testing of trypsin sensitivity was usually done by checking the presence of the HA band in a non-reducing gel of the tryptic digest. Digestion products 


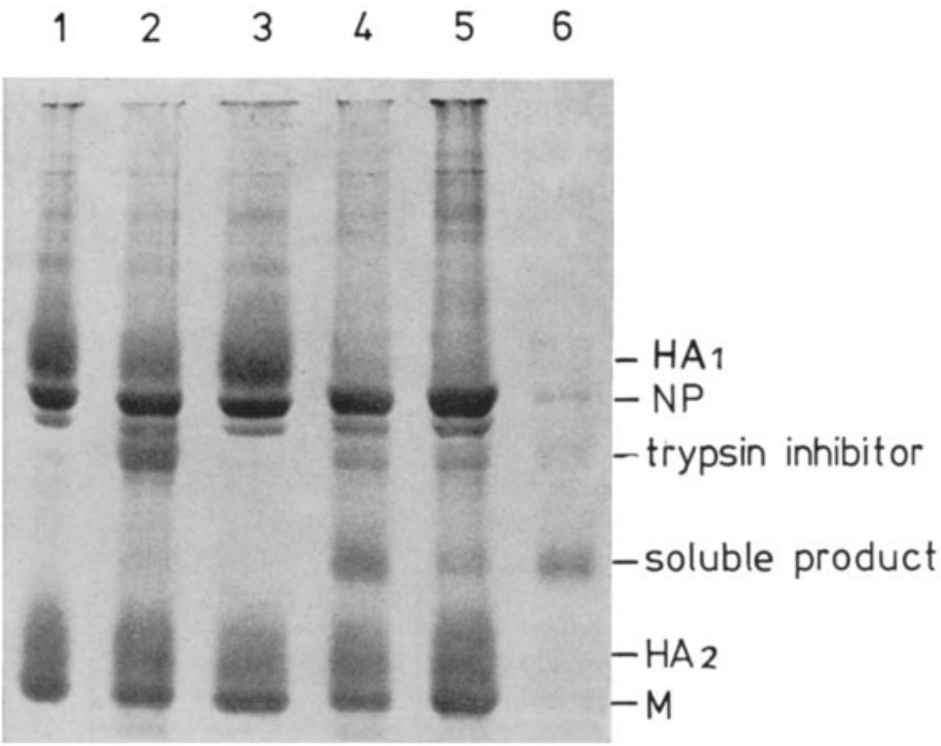

Fig. 3. Electrophoretic pattern of $\mathrm{X} 49$ virus under reducing conditions. The gel was stained with coomassie brilliant blue. 1 native virus; 2 native virus after tryptic digest; 3 low $\mathrm{pH}$ treated virus; 4 tryptic digest of low $\mathrm{pH}$ treated virus; 5 tryptic digest of low pH treated virus after removal of most of the soluble product by centrifugation; 6 soluble product of the tryptic digest in lane 5

Table 2. Summary of the pH thresholds and the acidic amino acid residues in the $\mathrm{N}$-terminus of $\mathrm{HA} 2$ of the studied strains

\begin{tabular}{|c|c|c|c|c|c|}
\hline \multicolumn{6}{|c|}{ Sequenceb } \\
\hline Strains & $\mathrm{pH}^{\mathrm{a}}$ & 11 & 15 & 19 & Reference \\
\hline X 31 & 5.1 & Glu & Glu & Asp & 32 \\
\hline$\times 49$ & 5.1 & -8 & & & \\
\hline A/Brasil & 5.2 & - & & & \\
\hline A/Texas & 5.1 & - & & & \\
\hline A/Japan & 5.7 & Glu & $G \ln$ & Asp & 8 \\
\hline A/WSN & 5.7 & Glu & Thr & Asp & 11 \\
\hline $\mathrm{A} / \mathrm{PR} / 8$ & 5.3 & GIu & Thr & Asp & 38 \\
\hline A/Vic & 5.2 & $\mathrm{CH}$ & Glu & Asp & 24 \\
\hline $\mathrm{A} / \mathrm{FPV}$ & 6.0 & Glu & GIu & Asp & 26 \\
\hline B/Lee & 5.5 & Glu & Glu & Ala & 17 \\
\hline B/Hong Kong & 5.8 & Glu & Glu & Ala & 18 \\
\hline $\mathrm{B} /$ Sing & 5.9 & Glu & Glu & Ala & 33 \\
\hline
\end{tabular}

a pH threshold value for the conformational change

b Aminoacid residues at positions 11,15 and 19 in $\mathrm{HA} 2$

c Not known 
were only studied in detail for the X49, A/Brazil, B/Hong Kong and B/Sing strains with reducing gels. In all cases the HA 1 was digested after low $\mathrm{pH}$ treatment whereas $\mathrm{HA} 2$ remained intact. The digestion products had a MW of 42,000 and 30,000 for A/Brazil, 42,000 and 30,000 for B/Hong Kong and 30,000 and 25,000 for B/Sing. In all cases the transition $\mathrm{pH}$ found by EM was identical to that found in the trypsin test. Furthermore, haemolysis tests were carried out for X49, A/Brazil, B/Hong Kong and $\mathrm{B} /$ Sing and again the same threshold $\mathrm{pH}$ values were found.

Influenza particles, exposed to a lower $\mathrm{pH}$ and subsequently treated with trypsin, were also studied by EM. As long as the virus had not been exposed to a $\mathrm{pH}$ below the threshold value the ordinary image with a well ordered spike layer was observed. Trypsin treatment of virus exposed to a $\mathrm{pH}$ below the threshold value resulted in spike layers that showed less disorder than the usual low $\mathrm{pH}$ particles. However, the spikes were much thinner than at $\mathrm{pH} 7$ and approximately $3.5 \mathrm{~nm}$ shorter (not shown).

\section{Virus with Uncleaved Haemagglutinin}

A/Texas virus was grown in embryonated eggs and in tertiary monkey kidney (tMK) cells with or without trypsin in the medium. Virus grown in tMK cells with trypsin contained cleaved HA. Such virus and egg-grown virus showed the normal low $\mathrm{pH}$ behaviour described above. The virus grown in $\mathrm{tMK}$ cells without trypsin in the medium contained precursor

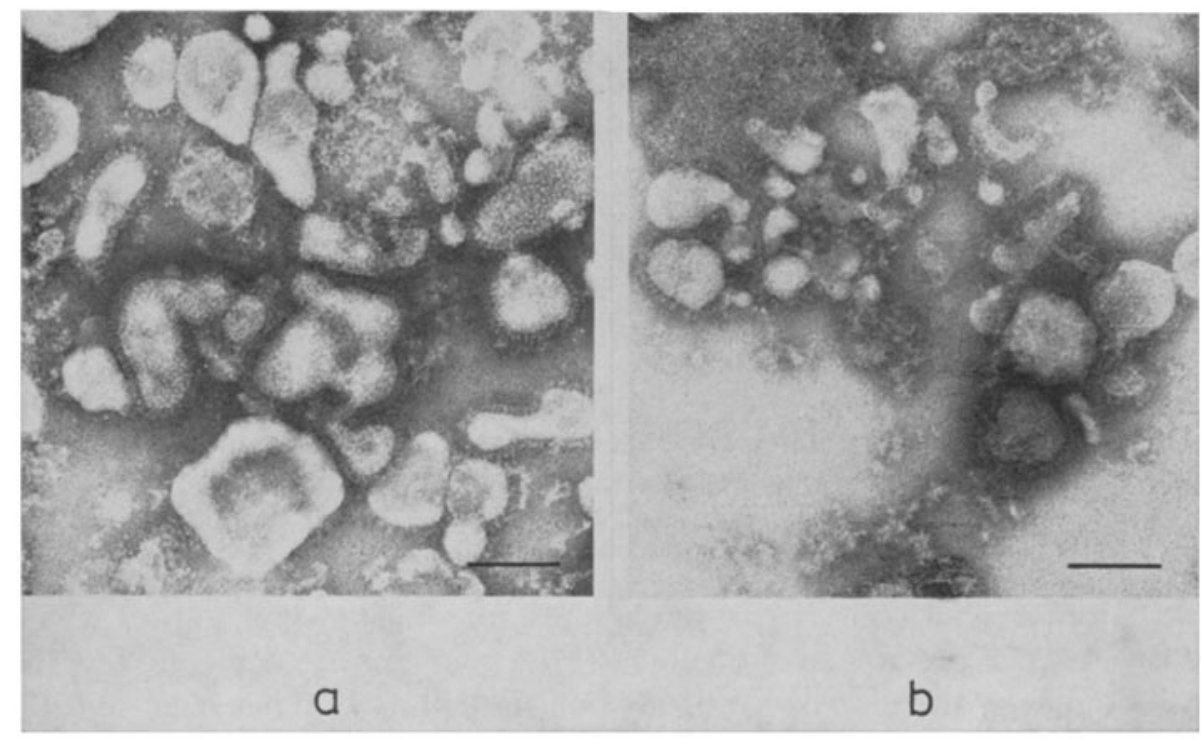

Fig. 4. Typical electron microscopic images of A/Texas virus. $a$ Virus containing HAo after low pH treatment. $b$ Virus grown on tMK-cells without trypsin. After isolation the virus was incubated with trypsin as described in the text and then incubated at low $\mathrm{pH}$. The bar represents $100 \mathrm{~nm}$ 
HAo and did not show a change at low $\mathrm{pH}$, as appeared from EM and trypsin sensitivity tests. Fig. 4 shows the EM image of the HAo virus at $\mathrm{pH}$ 5. The trypsin digestion resulted in breakdown of HAo to HA1 and HA2 but further breakdown did not occur. After the virus was treated with $40 \mu \mathrm{g} / \mathrm{ml}$ trypsin during 30 minutes at $37^{\circ} \mathrm{C}$, it behaved as egg grown virus when submitted to low $\mathrm{pH}$ treatment (Fig. 4).

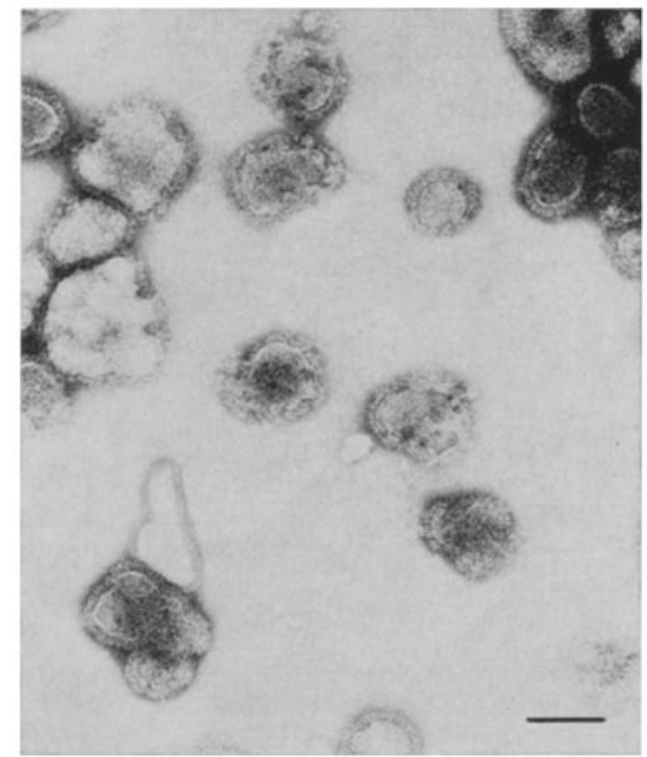

Fig. 5. Electron mierograph of an A/WSN virus preparation after incubation at pH 5.4. The preparation contains native particles with unchanged spikes and particles with a typical low $\mathrm{pH}$ appearance. The bar represents $100 \mathrm{~nm}$

\section{Heterogeneity of Particles Within a Strain}

The conformational change at low $\mathrm{pH}$ could also be induced by floating carbon film with adsorbed virus onto a low $\mathrm{pH}$ solution. Time dependent experiments showed the conformational change to be complete within 3 minutes. Therefore, dialysis overnight below the threshold $\mathrm{pH}$ would change all the sensitive HA. Some strains, however, showed a heterogeneity in the response of their HA to the low $\mathrm{pH}$ treatment. After dialysis below the threshold $\mathrm{pH}$ a small amount of $\mathrm{HA}$ was not sensitive to trypsix. digestion even after prolonged incubation for 36 hours. WeBster el al. (34) also observed that a small amount of $\mathrm{HA}$ had not undergone the conformational change below the threshold $\mathrm{pH}$. From electron microscopic images of A/WSN virus particles exposed to $\mathrm{pH} 5.4$ it was obvious that there were two kinds of particles, native and changed, see Fig. 5. This was further 
investigated by incubating the $\mathrm{A} / \mathrm{WSN}$ virus, which has a threshold $\mathrm{pH}$ of 5.7 , at $\mathrm{pH} 5.6$ before infecting embryonated eggs. The progeny virus was isolated and the threshold now turned out to be 5.4. We have determined the percentages of native and changed particles from electron micrographs after a dialysis to $\mathrm{pH}$ 5.6. Virus that was not pretreated at $\mathrm{pH} 5.6$ showed 77 per cent changed particles and virus that was pretreated at $\mathrm{pH} 5.6$ before infection showed only 21 per cent changed and 79 per cent native particles. Apparently the pH 5.6 treatment had inactivated the particles which normally change at $\mathrm{pH} 5.7$ and left the particles with a lower threshold $\mathrm{pH}$ infective. Again the results of EM and trypsin experiments were identical.

\section{Differences in pH Dependent Behaviour Between Strains}

When the sensitivity of the different strains to low $\mathrm{pH}$ was studied some differences between the strains became obvious. One of the differences was the fraction of virus which did not change below the threshold $\mathrm{pH}$ of most particles. This was evident for $\mathrm{A} / \mathrm{WSN}, \mathrm{B} /$ Hong Kong and B/Sing as mentioned above. Another difference concerned aggregation and precipitation of particles after dialysis below the threshold pH. B/Hong Kong, $\mathrm{B} /$ Sing and A/FPV showed much aggregation and precipitation after low $\mathrm{pH}$, whereas other strains did not show these effects. Neither restoring the $\mathrm{pH}$ to neutrality nor incubation with trypsin reversed the aggregation.

\section{The Influence of Bivalent Cations}

For a number of plant viruses a $\mathrm{pH}$ dependent conformational change involves a carboxylate cage $(2,14,15,25)$. Bivalent cations play an important role in these structures and may influence the threshold $\mathrm{pH}$ of the change. To investigate whether these cations also play a role in the HA conformational change, $\mathrm{X} 49$ and $\mathrm{B} /$ Hong Kong virus preparations were dialyzed to low $\mathrm{pH}$ in the presence of $10 \mathrm{mM} \mathrm{CaCl}, 10 \mathrm{~mm} \mathrm{MgCl}$ or 2 miv EDTA. The results showed that none of the additions changed the threshold $\mathrm{pH}$. Therefore we conclude that the mechanism of the conformational change does not involve a carboxylate cage.

\section{Discussion}

At low $\mathrm{pH}$ influenza virus causes fusion of membranes and haemolysis of erythrocytes. This behaviour is thought to reflect part of the infection process of the virus and the surface protein HA is responsible for these effects $(20,36)$. It was recently found that the soluble $H A$ isolated after bromelain treatment, $\mathrm{BHA}$, undergoes a conformational change at a $\mathrm{pH}$ 
value where haemolysis and fusion start to occur. This change resulted in aggregation of BHA at low $\mathrm{pH}$ and the emergence of new trypsin sensitive sites (30), changes in the antigenicity of the molecule $(4,34)$ and changes in the fluorescence spectrum of $\mathrm{HA}$ (27). Our results show that this conformational change is also apparent in electron microscopic images of whole virus particles and that new tryptic sites are also generated in HA while still assembled on the virus.

In $\mathrm{BHA}$ of $\mathrm{X} 31$ virus the new tryptic sites exposed after the low $\mathrm{pH}$ treatment are Lys 27 and Arg 224 in HA 1 (30). Although the HA1 sequences of A/Japan, A/PR/8 and A/FPV do not contain trypsin sensitive residues at these positions, there still was breakdown of HA. HA1 of A/WSN also does not have a cleavable site at position 27. Maybe other sites near these positions become available for cleavage as well. A possible candidate is residue 32 which is Lys or Arg in the above mentioned strains and Asp in X 31 .

The EM image of low $\mathrm{pH}$ treatment virus shows a disordered spike layer. This might be caused by a more flexible structure of the spikes after low $\mathrm{pH}$ treatment. Irregular aggregation of the spikes will also result in a disorder of the spike layer. Aggregation of spikes on the particle was never observed to such an extent that naked patches of membrane became available which has been suggested as a possible fusion mechanism (30). Treating the virus with trypsin after the low $\mathrm{pH}$ exposure resulted in particles with a spike layer that was reduced $3.5 \mathrm{~nm}$ in thickness. The spikes appeared thinner than in normal virus and more ordered than the pH 5 treated spike before trypsin treatment. We found that the HA2 is left on the virus after trypsin digestion. X-ray studies (37) showed that HA 2 extends to about $3.5 \mathrm{~nm}$ from the distal tip which corresponds nicely with the decrease in spike layer width as determined by FM. A large part of the HA triple helix stem structure was removed which might make the resulting spike appear thin. The soluble product after trypsin cleavage is a monomer (30). From our EM observations it is not clear if the part of the HA spike that remains on the virus surface after trypsin digestion is still in a trimeric state.

Influenza virus contains two different types of surface glycoprotein spikes, HA and neuraminidase. In the EM observations of the low pH experiments the whole virus was studied. At the $\mathrm{pH}$ threshold we observed a change in all the spikes on the particles and there did not appear to be two kinds of spikes with differences in behaviour with respect to low $\mathrm{pH}$. It might be argued that the flexibility or aggregation of the changed HA molecules blurred the presence of the neuraminidase (NA). Furthermore the NA may also undergo a change at low $\mathrm{pH}$. NA activity measurements before and after the low $\mathrm{pH}$ treatment showed a reduction of 50 to 80 per cent. 
The $\mathrm{N}$-terminus of $\mathrm{HA} 2$ of influenza virus shows sequence homology with the hydrophobic $\mathrm{N}$-terminus of the fusion peptide of sendai virus. However, this sendai peptide does not contain the acidic residues that are present in the HA2 N-terminus which might be the reason why sendai causes fusion and haemolysis even at neutral $\mathrm{pH}$. The acidic residues in the HA $2 \mathrm{~N}$-terminus are thought to be protonated at low $\mathrm{pH}$ after which fusion can take place (21). Therefore we investigated the effect of the absence or substitution of these acidic residues in HA2. Several strains with less than 3 acidic residues in the HA2 aminoterminus were tested and, as can be seen in Table 2, the number and kind of acidic residues are not reflected in the threshold $\mathrm{pH}$. We can also exclude the involvement of a carboxylate cage in the change since bivalent cations do not influence the threshold $\mathrm{pH}$.

All strains showed essentially the same changes after exposure to low $\mathrm{pH}$. Some differences between strains were observed in the aggregation of the particles. It is interesting to note that the three strains with the highest value for the threshold $\mathrm{pH}$ also aggregated stronger than the other strains. Virus preparations of $\mathrm{B} / \mathrm{H}$ ong Kong, B/Sing and $\mathrm{A} / \mathrm{WSN}$ were shown to be heterogeneous with respect to the threshold $\mathrm{pH}$. Our experiments showed that this phenomenon may be due to genetic differences among the virus population. Recently WEBSTER and coworkers (34) found that about 15 per cent of the HA molecules did not change at the threshold $\mathrm{pH}$. DE Jong and coworkers (5) and SCHrLD and coworkers (28) reported the presence of several subpopulations of virus particles with different antigenic characters in the same virus isolate. The difference in heterogeneity between strains may explain why some strains show a narrow range of threshold $\mathrm{pH}$ 's and other strains a much wider range (12).

For infection, haemolysis and fusion of cells the HA must be in its cleaved state. Virus with HAo is inactive in these three functions. As appears from our experiments HAo does not undergo a conformational change at low $\mathrm{pH}$ which confirms recent results of DANIELs and coworkers (4). This is a further indication that the observed low $\mathrm{pH}$ change is indeed connected to a step in the infection process of influenza virus.

\section{Acknowledgements}

We thank Duphar BV (Weesp, Holland) for their donation of some of the virus strains we have used in this work, Marianne Booms-Heijtink for growing the other strains, Dr. Mädeli Hennekam for performing some of the experiments, Dr. John Skehel for stimulating discussions and Dr. Piet Jan Andree for critically reading the manuscript. This work was supported by grants from the Netherlands Foundation for Chemical Research (S.O.N.) and the Netherlands Organization for the Advancement of Pure Research (Z.W.O.). 


\section{References}

1. Aymard-Henry, M., Coleman, M. T., Dowdle, W. R., Laver, W. G., Schild, G. C., Webster, R. G.: Influenza virus neuraminidase and neuraminidaseinhibition test procedures. Bull. Wld. HIth. Org. 49, 199-202 (1973).

2. Bancroft, J. B., Hills, G. J., Markeam, R. : A study of the self-assembly process in a small spherical virus. Formation of organized structures from protein subunits in vitro. Virology 31, 354-379 (1967).

3. Bukrinskaya, A. G., Vorkunova, N. K., Kornulayeva, G. V., Narmanbetova, R. A., Vorkunota, G. K.: Influenza virus uncoating in infected cells and effect of rimantidine. J. gen. Virol. 60, 49-59 (1982),

4. Daniels, R. A., Douglas, A. R., Skehel, J. J., Wirey, D. C.: Analysis of the antigenicity of influenza virus haemagglutinin at the $\mathrm{pH}$ optimum of virus mediated membrane fusion. J. gen. Virol. 64, 1657-1662 (1983).

5. De Jong, J. C., de Ronde-Vertoop, F. M., Veenendaal-van Herk, T. M.: Variability of influenza virus in respect to antigenic reactivity. Abstracts Regular Meeting European Association against Virus Disease, Munich, 1979.

6. Draper, R. K., Simon, M. I.: The entry of diphteria toxin into the mammalian cell cytoplasm: evidence for lysosomal involvement. J. Cell Biol. 87, 849-854 (1980).

7. Gething, M. J., White, J. M., WAterfield, M.: Purification of the fusion protein of sendai virus: Analysis of the $\mathrm{NH}_{2}$-terminal sequence generated during precursor activation. Proc. Natl. Acad. Sci. U.S.A. 75, 2737-2740 (1978).

8. Gethrng, M. J., Bre, J., Skehel, J., WATERFIELD, M.: Cloning and DNA sequence of double stranded copies of haemagglutinin genes from $\mathrm{H} 2$ and $\mathrm{H} 3$ strains elucidates antigenic shift and drift in influenza virus. Nature 287, 301-306 (1980).

9. Helientus, A., Kartenbeck, J., Simons, K., Fries, E,: On the entry of semliki forest virus into BHK-21 cells. J. Cell Biol. 84, 404-420 (1980).

10. Helentus, A., Marsh, M., White, J.: Inhibition of semliki forest virus penetration by lysomotropic weak bases. J. gen. Virol. 58, 47-61 (1982).

11. Hrti, A. L., Davies, A. R., NAYAK, D. P.: Complete sequence analysis shows that the haemagglutinin of the $\mathrm{H} 0$ and $\mathrm{H} 2$ subtypes of human influenza virus are closely related. Virology 111, $113-124$ (1981).

12. Hosaka, Y., Seriburi, O., Morax, M. G., Yasuda, Y., Fukat, K., Nerome, K.: Haemolysis and fusion by influenza viruses with heat inactivated neuraminidase activity. Biken J. 25, 51-62 (1982).

13. Huang, R. T., Rott, R., KuenK, H.-D.: Influenza virus causes haemolysis and fusion of cells. Virology 110, 243-247 (1981).

14. Incardona, N. L., MoKeg, S., Flanagan, J. B.: Noncovalent interactions in viruses. Characterization of their role in the $\mathrm{pH}$ and thermally induced changes in bromegrass mosaic virus. Virology 53, 204-214 (1973).

15. JACROT, B. : Studies on the assembly of a spherical plant virus. IT. The mechanism of protein aggregation and virus swelling. J. Mol. Biol. 95, 433-446 (1975).

16. Kuenk, H.-D., Rott, R., OHritch, M., Blodorn, J.: Activation of influenza A viruses by trypsin treatment. Virology $68,426-439$ (1975).

17. Krystal, M., Elilot, R. M., Benz, E. W., JR., Young, J. F., Palese, P.: Evolution of influenza $A$ and $B$ viruses: Conservation of structural features in the haemagglutinin genes. Proc. Natl. Acad. Sci. U.S.A. 79, 4800-4804 (1982).

18. Krystal, M., Young, J. F., Palese, P., Wilson, I. A., Skehex, J. J., Wiley, D. C.: Sequential mutations in hemagglutinins of influenza $B$ virus isolates: Definition of antigenie domains. Proe. Natl. Acad. Sei. U.S.A. 80, 4527-4531 (1983). 
19. Lazarowitz, S. G., Choppin, P. W.: Enhancement of the infectivity of influenza $A$ and $B$ viruses by proteolytic cleavage of the hemagglutinin polypeptide. Virology 68, 440-454 (1975).

20. Lenard, J., Bailey, C. A., MrLler, D. K.: pH dependence of influenza A virusinduced hemolysis is determined by the haenagglutinin gene. J. gen. Virol. 62, $353-355$ (1982).

21. MAEda, T., OHnishi, S.-I.: Activation of influenza virus by acidic media causes hemolysis and fusion of erythrocytes. FEBS Lett. 122, 283-287 (1980).

22. Maeda, T., KAwasakI, K., OHNoshx, S.-I.: Interaction of influenza virus hemagglutinin with target membrane lipids is a key step in virus induced hemolysis and fusion at $\mathrm{pH}$ 5.2. Proc. Natl. Acad. Sci. U.S.A. 78, 4133-4137 (1981).

23. Matuin, K. S., RegGro, H., Herenius, A., Simons, K. Infection entry pathway of influenza virus in a canine kidney cell line. $J$. Cell Biol. 91, 601-603 (1981).

24. Mrn Jou, W., Verhofyen, M., Drvos, R., Samon, E., Fang, R., Huyterroek, D., FIERs, W.: Complete structure of the hemagglutinin gene from the human influenza A/Victoria/3/75 (H3N2) strain as determined from cloned DNA. Cell 19,683-696(1980).

25. Pfeiffer, P., DuRham, A. C. H.: The cation binding associated with structural transitions in bromegrass mosaic virus. Virology 81, 419-432 (1977).

26. Porter, A. G., Barber, C., Carex, N.H., Hallmweld, R. A., Threlfall, G., Emtace, J. S.: Complete nucleotide sequence of an influenza virus haemagghtinin gene from cloned DNA. Nature 282, 471-477 (1979).

27. Sato, S. B., Kawasakt, K., OHNIshi, S.-I.: Hemolytic activity of influenza virus hemagglutinin glycoproteins activated in mildly acidic environments. Proc. Natl. Acad. Sci. U.S.A. 80, 3153-3157 (1983).

28. Schild, G. C., Oxford, J. S., de Jong, J. C., Webster, R. G.: Evidence for host-cell selection of influenza virus antigenic variants. Nature 303, 706-709 (1983).

29. Skenel, J. J., Watfrfield, M. D.: Studies on the primary structure of the influenza virus hemagglutinin. Proe. Natl. Acad. Sci. U.S.A. 72, 93-97 (1975).

30. Skehel, J. J., Bayley, P. M., Brown, E. B., Martin, S. R., Waterfield, M. D., White, J. M., WILson, I. A., WILEY, D. C. : Changes in the conformation of the influenza virus hemagglutinin at the $\mathrm{pH}$ optimum of virus mediated membrane fusion. Proc. Natl. Acad. Sci. U.S.A. 79, 968-972 (1982).

31. VAananen, P., KaARIaInen, L.: Fusion and haemolysis of erythrocytes caused by three togaviruses: semliki forest virus, sindbis and rubella. J. gen. Virol. 46, $467-475(1980)$.

32. Verhoeyen, M., Fang, R., Mtn Jou, W., Devos, R., Huylebrotek, D., Samon, E., Fters, W.: Antigenic drift between the haemagglutinin of the Hong Kong influenza strains A/Aichi/2/68 and A/Victoria/3/75. Nature 286, 771-776 (1980).

33. Vermoeyen, M., Van Rompuy, L., Min Jou, W., Huylebroeck, D., Fiers, W.; Complete nucleotide sequence of the B/Singapore/222/79 virus hemagglutinin gene and comparison with the B/Lee/40 hemagglutinin. Nuel. Acids Res. 11, $4703-4712(1983)$.

34. WEBSter, R. G., Brown, L. E., JACksoN, D. C.: Changes in the antigenicity of the hemagglutinin molecule of $\mathrm{H} 3$ influenza virus at acidic $\mathrm{pH}$. Virology 126, $587-599(1983)$.

35. WHITE, J., HelenNus, A.: pH dependent fusion between semliki forest virus membrane and liposomes. Proc. Natl. Acad. Sci. U.S.A. 77, $3273-3277$ (1980).

36. White, J., Helenjus, A., Gethung, M.-J.: Haemagglutinin of influenza virus 
expressed from a cloned gene promotes membrane fusion. Nature 300, 658-659 (1982).

37. Wilson, I. A., SkeHel, J. J., WILEY, D. C.: Structure of the haemagglutinin membrane protein of influenza virus at $3 \AA$ resolution. Nature $289,366-373$ (1981).

38. Winter, G., Fuflds, S., Brownlee, G. G.: Nucleotide sequence of the haemagglutinin gene of a human influenza virus $\mathrm{H} 1$ subtype. Nature $292,72-75$ (1981).

Authors' address: Dr. R. W. H. RuraroK, Biochemisch Laboratorium, Rijksuniversiteit Leiden, Department of Biochemistry, State University Leiden, Wassenaarseweg 64, NL-2333 Al Leiden, The Netherland.

Received February 27, 1984 